\section{Diálogo na interface dos campos Saúde Coletiva e Educação Física}

Dialogue at the interface of the fields of Public Health and Physical Education

Júlia Aparecida Devidé Nogueira ${ }^{1}$

Maria Lúcia Magalhães Bosi²

${ }^{1}$ Programa de Pós-Graduação em Educação Física, Faculdade de Educação Física, Universidade de Brasília. Brasília DF Brasil.

${ }^{2}$ Programa de Pós-Graduação em Saúde Coletiva, Departamento de Saúde Comunitária, Faculdade de Medicina, Universidade Federal do Ceará. Fortaleza CE Brasil.

Primeiramente, é preciso registrar quão gratificante foi receber o comentário concernente ao nosso manuscrito, expressando um aceite à reflexão. Em tempos de uma afirmação avassaladora do neoliberalismo na ciência ${ }^{1}$, onde o produtivismo não estimula e nem premia o debruçar-se sobre o texto do outro, o exercício que nos chega se reveste de um valor inestimável. O que o autor chama de "apontamentos complementares" nos possibilita ampliar as margens da construção anterior e, também, esclarecer o que a concisão, por vezes, omite.

Sobre a consideração relativa à história da Educação Física $(\mathrm{EF})$, concordamos que a inclusão da ginástica nas escolas no século XIX é elemento seminal do discurso higienista e eugenista na educação dos corpos. No entanto, ao abordar distanciamentos e interfaces entre EF e Saúde Coletiva (SC) adotamos a demarcação da constituição dos campos, consoante à concepção de Bourdieu $^{2}$, portanto, à configuração desse campo como campo científico, o que, na EF, ocorre no início do século XX.

$\mathrm{O}$ autor menciona a não incorporação da noção "identidades marginais" que, sim, conversa com o que procuramos apontar na apropriação dos corpos pela lógica da sociedade de consumo na hipermodernidade ${ }^{3}$. Questões como a culpabilização e a estigmatização vem sendo assinaladas por uma gama de autores que, para além de apontar a consequente exclusão, denunciam questões como gênero e classe que incidem fortemente sobre grupos sociais alvos de rótulos os mais variados. Tal análise, contudo, não se resolveria com a incorporação da referida noção, haja vista a complexidade de que se reveste a emergência dos ideais de corpo e de estilos de vida, construções sociais que produzem o "gordo preguiçoso" e o "sedentário sem vergonha".

Bourdieu ${ }^{4}$ nos ajuda a compreender como diferenças diferenças biológicas expressam e justificam assimetrias. Assim, o corpo, em uma perspectiva (bio) política, "é situado na concretude, enquanto volume materializado, mas sempre resultado de investimentos de poder e de enunciações por parte dos saberes que o montam e o constroem como valor"5. O discurso culpabilizador omite a experiência humana para se sustentar como ideologia cuja circulação se apoia em mecanismos vários correspondendo ao que Foucault ${ }^{6}$ concebe como dispositivo. Vale considerar a cumplicidade entre o saber médico e o arsenal midiático na construção de identidades, sejam elas marginais ou, no sentido oposto, "celebridades" vinculadas ao corpo perfeito.

Tais reflexões constituem outro objeto e exigem um espaço que escaparia aos limites do manuscrito. Espaço que permitisse convidar, além do mencionado Daolio ${ }^{7}$, Foucault ${ }^{6}$, Bourdieu ${ }^{4}$ e Agambem ${ }^{8}$, e autores da Sociologia do Corpo como Lipovetsky9 e Le Breton ${ }^{10}$, para analisar como se constroem essas "verdades" e como se processam disputas de narrativa em torno de corpos - sedentários, obesos, belos, sarados, e tudo que a eles se adiciona. E desvelar práticas discursivas hegemônicas como forma de controle corporal. Não tendo sido o propósito abarcar todo esse conteúdo, aludimos ao referencial das ciências sociais e humanas - que inclui e ultrapassa o conceito de cultura - por se tratar de uma análise acerca da configuração epistemológica do campo ${ }^{2}$.

Por fim, sobre a questão da formação profissional em EF, cabe concordar que é na formação do bacharel que as interfaces entre EF e SC têm se adensado. Mas a discussão sobre a unificação da formação é muito mais ampla e complexa que a expressa na distância entre os saberes do bacharelado e da licenciatura e na tensão entre os modelos biomédico e das ciências sociais. Há que se questionar sobre os modelos de formação em geral, o que se refere à formação inicial, ao papel da educação continuada e às especialidades (ou especializações) dentro do campo. Para tal haveríamos que adentrar discussões sobre construção curricular e competências na formação, dentre tantos outros assuntos que ficarão para uma próxima conversa... 


\section{Referências}

1. Oliveira MBD. A avaliação neoliberal na universidade e a responsabilidade social dos pesquisadores. Scientia e Studia 2008; 6(3):379-387.

2. Bourdieu P. O campo científico. In: Ortiz R, organizador. Pierre Bourdieu: Sociologia. São Paulo: Ática; 1983.

3. Bauman Z. Modernidade líquida. Rio de Janeiro: Zahar; 2001.

4. Bourdieu P. O poder simbólico. Rio de Janeiro: Bertrand Brasil; 1990.

5. Oliveira FP, Bosi MLM, Vigário P, Vieira R. Comportamento Alimentar Anormal e Imagem Corporal em Atletas. RBME 2003; 9(6):357-364.

6. Foucault M. Vigiar e punir. Petrópolis: Vozes; 1987.

7. Daolio J. Educação Física e o conceito de cultura. Campinas: Autores Associados; 2005.

8. Agambem G. O queéo contemporâneo? E outros ensaios. Chapecó: Argos-Unochapecó 2009.

9. Lipovetsky G. O império do efêmero. São Paulo: Companhia das Letras; 1989.

10. Le Breton D. A sociologia do corpo. Petrópolis: Vozes; 2006. 